\title{
Synthesis of Diazepine-fused Porphyrinoids and Annulated Porphyrin Arrays
}

Aoife A. Ryan, ${ }^{\text {a }}$ Fanny Pouyatos, ${ }^{\text {a }}$ Aurelie Stallivieri, ${ }^{\mathrm{a}}$ Teodor Silviu Balaban, ${ }^{\mathrm{b}}$ and Mathias O. Senge $e^{a, c^{*}}$

a School of Chemistry, SFI Tetrapyrrole Laboratory, Trinity Biomedical Sciences Institute, 152-160 Pearse Street, Trinity College Dublin, Dublin 2, Ireland

${ }^{\mathrm{b}}$ Aix Marseille Université, CNRS, UMR iSm2 7313, F-13397 Marseille, France

${ }^{c}$ Medicinal Chemistry, Institute of Molecular Medicine, Trinity Centre for Health

Sciences, Trinity College Dublin, St James's Hospital, Dublin 8, Ireland

Reprint requests to Prof. Dr. M. O. Senge. Fax: \#353-1-896-8537. E-mail: sengem@tcd.ie

\section{Z. Naturforsch. 2014, XXb, XXXX-XXXX; received XXXXX}

Porphyrins with exocyclic rings allow for significant modulation of the photochemical properties of the macrocycle via modulation of the aromatic system through electronic and conformational effects. Here we sought to generate such porphyrinoids via a stepwise strategy involving two cycloaddition steps, the first improving the synthesis of a relatively unstable dehydropurpurin intermediate which ring opens to form a key 1,5-diketone species. A library of a new class of porphyrinoids, namely diazepine-fused porphyrinoids was synthesized via condensation methods from these 1,5-diketone precursors in yields of 8-49\%. Cycloaddition methodologies were also applied to bisporphyrins and their reactivities were investigated.

Key words: Porphyrinoids, Cycloaddition, Diazepine, 1,5-Diketones 


\section{Introduction}

Tetrapyrroles with exocyclic rings have great biological significance, and there are numerous synthetic derivatives of such [1-3]. Depending on the exocyclic ring size a perturbation of the macrocycle is often observed, and these distorted porphyrinoids have interesting photophysical properties and exhibit bathochromic shifts in their absorption profiles [4]. The development of such compounds is attractive for the purpose of applying to areas such as two-photon photodynamic therapy (2PA-PDT), whereby an enhancement of absorption is desirable for the targeting of deeper cancers and in the development of self-assembling solar cells, which have the capacity to mimic biological light-harvesting systems [5]. Our aim was to synthesize novel porphyrinoids incorporating heterocyclic exocyclic rings, namely diazepine derivatives and investigate their photophysical properties, with the overall objective of applying them to PDT, or, via supramolecular constructs, in solar cells.

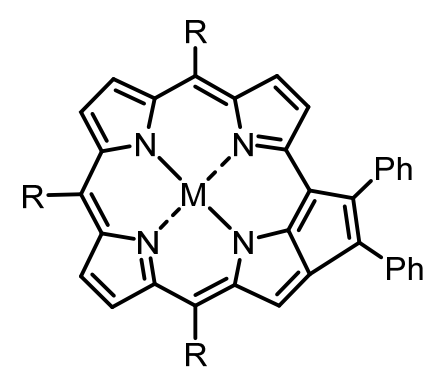

7,8-dehydropurpurin

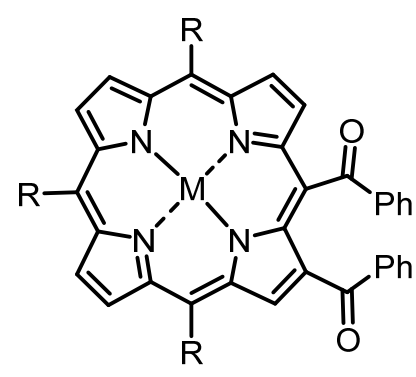

1,5-diketone porphyrin

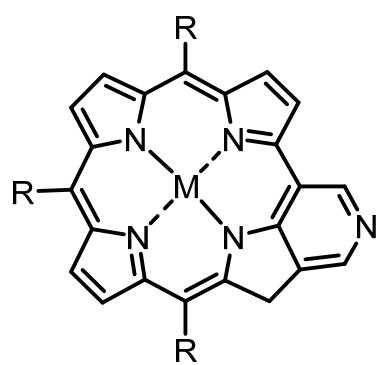

oxopyridochlorin

Fig. 1. General formulas for 7,8-dehydropurpurin, 1,5-diketone porphyrin and oxopyridochlorin.

Numerous investigations into various cycloaddition reactions on monomeric porphyrins, generating perturbed macrocycles with enhanced photophysical properties 
have been executed [6-8]. These include various strategies such as Grubbs metathesis, 1,3-dipolar cycloadditions, and intramolecular oxidative coupling, to name but a few. We decided to adopt the attractive [3+2] annulation strategy developed by Osuka and coworkers [9] involving a palladium-catalyzed C-C bond forming reaction via carbopalladation of a bromo-porphyrin with internal alkynes [10,11]. The resulting product is a 7,8-dehydropurpurin bearing a fused cyclopentadiene ring (Fig. 1) which causes a significant distortion of the porphyrin macrocycle, which, upon ring opening of zinc(II) derivatives, forms a 1,5-diketone porphyrin (Fig. 1). Diketones readily undergo intramolecular cyclization reactions with various nucleophiles to form heteroaromatic compounds such as pyrylium salts, pyridines and diazepines and this reactivity will be exploited. For example, the reaction of 1,5-diketones with various amino derivatives is widely known, with the resulting generation of nitrogen containing heterocycles [12]. Osuka and co-workers utilized this methodology to generate a novel pyridine-fused porphyrinoid, namely an oxopyridochlorin, (Fig. 1) which like the dehyropurpurins, exhibit a substantial red-shift into the near-IR region due to enhanced conjugation and distortion of the macrocycle. Here we report a similar strategy with the goal of generating diazepine porphyrinoids.

\section{Results and Discussion}

As we described previously, the initial strategy which we undertook involved the proposed synthesis of a triply fused dimeric dehydropurpurin [13]. Although [3+2] annulation occurred, the predominant product isolated was a 1,5-diketone porphyrin due to the instability of zinc(II) 7,8-dehydropurpurins. In order to further exploit the utility of these materials, we synthesized a library of dehydropurpurins 2a-e using the [3+2] 
annulation strategy. Using bromoporphyrins 1a-e, a $\mathrm{Pd}(0)$-catalyzed reaction of a double bond on the bromoporphyrin with the internal alkyne diphenylacetylene, porphyrins 2a-e were generated in good to excellent yields of up to $85 \%$ yields (Scheme 1).

The zinc-dehydropurpurins are unstable in dilute solution, and on exposure to air and light, the cyclopentadiene ring opens, to give 1,5-diketones 3a-e in almost quantitative yields. This is not seen with nickel(II) or palladium(II) porphyrins and is thus presumed to occur from singlet oxygen generation. As shown in Scheme 2, a plausible mechanism for the ring opening includes a light-initiated [2+2] cycloaddition of singlet oxygen with the external double bond to give a dioxetane intermediate. This then decomposes to yield the diketone product. [14]

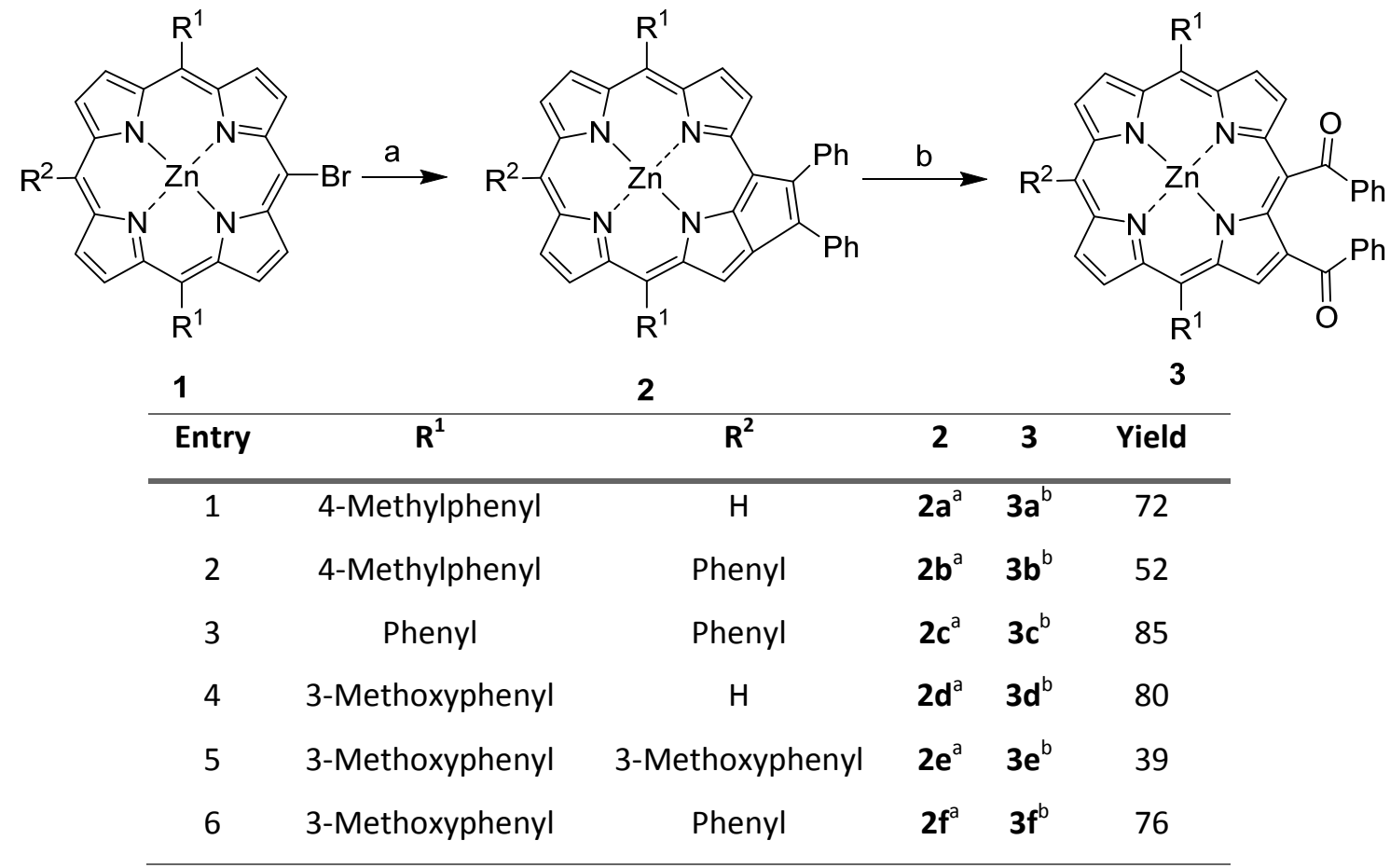

${ }^{a}$ Diphenylacetylene (1.5 eq.), $\mathrm{Pd}_{2}(\mathrm{dba})_{3}(5 \%),(o-\mathrm{Tol})_{3} \mathrm{P}(0.2$ eq. $)$, toluene, $N, N$ dicyclohexylmethylamine (5 eq.), $120{ }^{\circ} \mathrm{C}, 24 \mathrm{~h},{ }^{\mathrm{b}} \mathrm{CHCl}_{3}$, air, light, $24 \mathrm{~h}$.

Scheme 1. Synthesis of porphyrin-3,5-bisketones. 


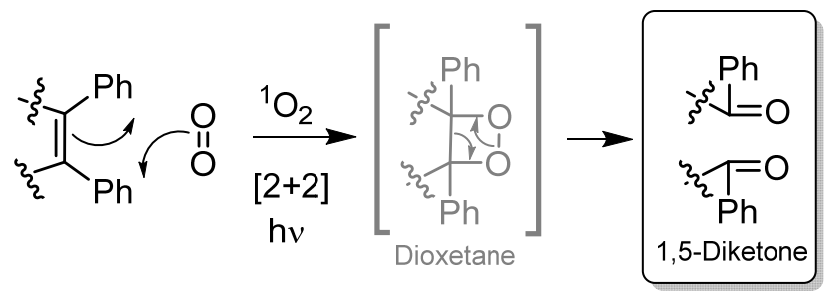

Scheme 2. Ring opening mechanism.

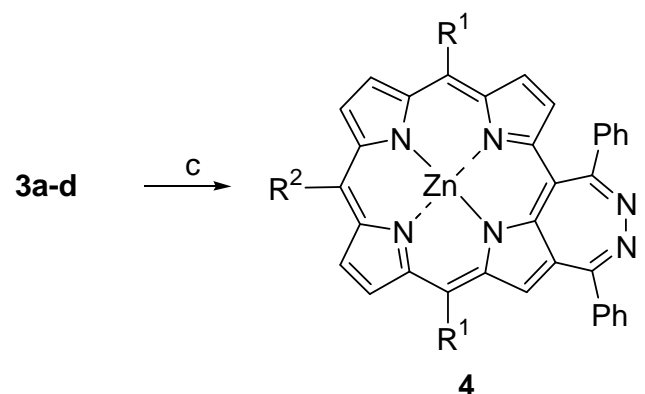

\begin{tabular}{ccccc}
\hline Entry & $\mathbf{R}^{\mathbf{1}}$ & $\mathbf{R}^{\mathbf{2}}$ & $\mathbf{4}$ & Yield (\%) \\
\hline $\mathbf{1}$ & 4-Methylphenyl & $\mathrm{H}$ & $\mathbf{4 a}$ & 8 \\
$\mathbf{2}$ & 3-Methoxyphenyl & Phenyl & $\mathbf{4 b}$ & $49^{\mathrm{a}}$ \\
$\mathbf{3}$ & 3-Methoxyphenyl & $\mathrm{H}$ & $\mathbf{4 c}$ & $\mathrm{n} / \mathrm{d}^{\mathrm{b}}$ \\
$\mathbf{4}$ & 3-Methoxyphenyl & 3-Methoxyphenyl & $\mathbf{4 d}$ & 12 \\
\hline
\end{tabular}

${ }^{\mathrm{a}} \mathrm{MW}$ conditions, ${ }^{\mathrm{b}}$ not isolated due to difficulties with purification. HRMS (MALDI): $m / z$ calculated for $\left[\mathrm{C}_{48} \mathrm{H}_{33} \mathrm{~N}_{6} \mathrm{O}_{2} \mathrm{Zn}\right] 789.1956$, found 789.1948 .

Scheme 3. Synthesis of diazepine derivatives. Reagents and conditions: ${ }^{\mathrm{c}}$ Hydrazine hydrate (10 eq.), EtOH/acetic acid, reflux or MW.

The reactivity of these 1,5-diketones was further investigated as they are widely known to undergo various cyclization reactions to give 5-, 6- and 7-membered ring products, depending on the reagent and conditions used [15-17]. We decided to use hydrazine as a substrate to develop a novel diazepine-fused porphyrin, to explore the reactivity of the porphyrin 1,5 -diketones generated and the effect that the fused diazepine moiety would have on the macrocycle. Condensation of 1,5-diketones 3a-e [9] with hydrazine hydrate yielded the desired diazepine products $4 a-d$ in yields of up to $49 \%$ (Scheme 3). Numerous conditions were explored; with the optimum yield obtained 
employing a microwave as the heat source. Although the synthesis gave moderate yields, the reaction was not as successful in terms of yields as that for the pyrydiniumporphyrinoid. The condensation mechanism begins with the protonation of the carbonyl oxygen under acidic conditions and subsequent nucleophilic attack of hydrazine at the electrophilic carbon. A series of proton transfer and elimination of water yields a hydrazone intermediate. Another attack by the hydrazine moiety, this time intramolecularily, closes the ring. Subsequent proton transfer and loss of water yields the 1,2-diazepine porphyrin. Attack by the other nitrogen would generate a 6-membered annulated ring (such as a $N$-amino-pyridinium salt), which due to loss of global aromaticity, however, was not detected. These are novel fused porphyrinoid systems, although the macrocycle here is not perturbed as observed for the [3+2] adduct and pyridinium derivative. Attempts to generate pyrylium salt derivatives via a similar strategy [18-20] were largely unsuccessful.

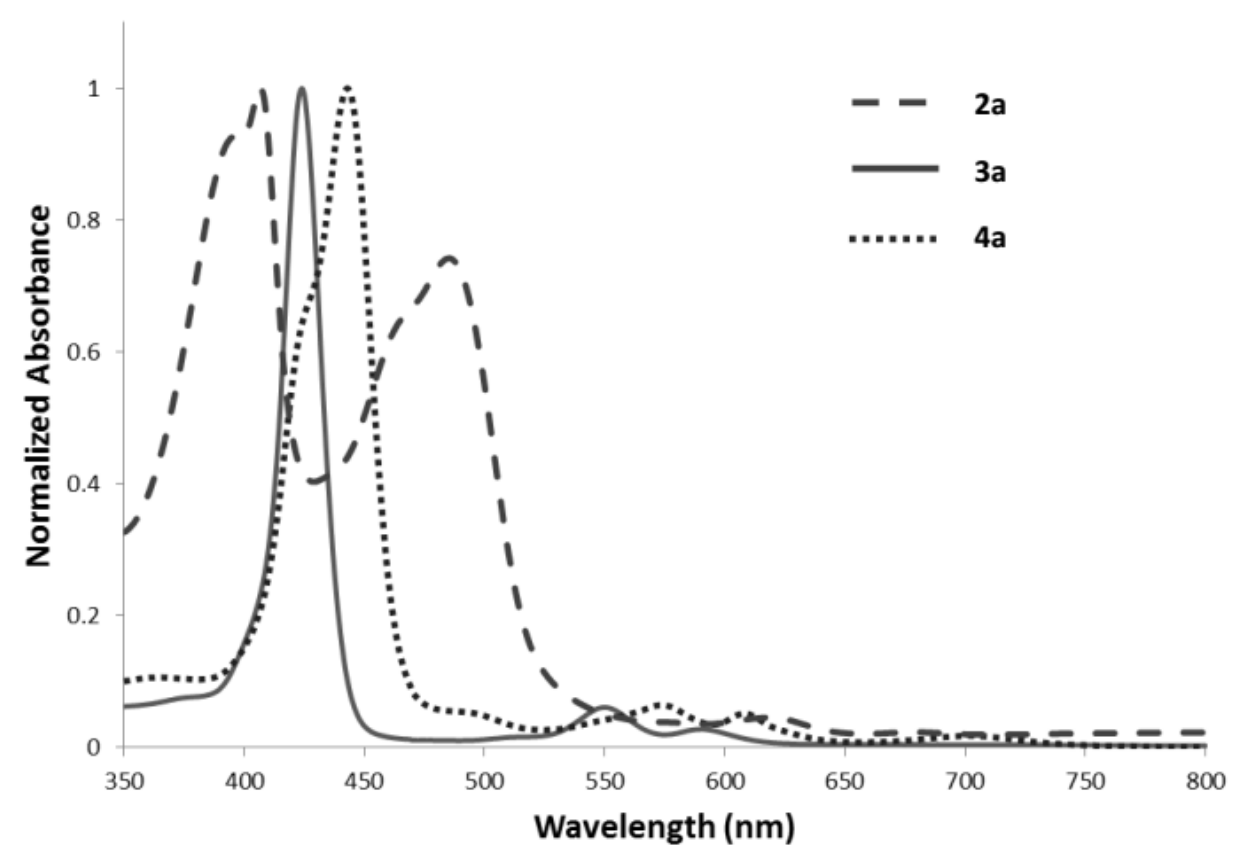

Fig. 2. Normalized absorption spectra of $\mathbf{2 a}$, 3a and $4 \mathbf{a}$ in $\mathrm{CH}_{2} \mathrm{Cl}_{2}$. 
The UV-Vis absorption spectra of porphyrins 2a, 3a and 4a are shown in Fig. 2. Due to the perturbation of the macrocycle in $\mathbf{2 a}$ a split in the Soret band is observed. On returning to aromaticity in 3a, a typical porphyrin absorption is seen. The diazepine adducts are characterized by broad Soret bands and also a slight bathochromic shift compared to their 1,5-diketone precursors.

Fig. 3 shows a comparison of the NMR spectra of bromoporphyrin 1f, dehydropurpurin $\mathbf{2 f}$, 1,5-diketone porphyrin 3f, and the diazepine-fused porphyrin $\mathbf{4 b}$. On generation of $\mathbf{2 f}$ from bromoporphyrin 1f, there was a substantial increase in shielding of $\beta$-signals from between 8.8 and $9.8 \mathrm{ppm}$ to 7.2 to $8.2 \mathrm{ppm}$. Also, with $\mathbf{1 f}$ there are four $\beta$ proton signals, with six signals for the $\beta$-protons in $\mathbf{2 f}$, due to the distortion of the macrocycle. This is most evident for the $\beta$-protons closest to the cyclopentadiene ring which occurs as two singlets. The methoxy $\mathrm{CH}_{3}$ signal for $\mathbf{1 f}$ occurs as a $6 \mathrm{H}$ singlet but with $2 \mathrm{f}$, two $3 \mathrm{H}$ singlets are observed due to the asymmetry of the macrocycle. Some impurities are present in the spectrum of $\mathbf{2 f}$, as here the ring opening was promoted to generate diketone $\mathbf{3 f}$. The spectrum for $\mathbf{3 f}$ returns to that for a porphyrin with the $\beta$ signals resonating in the region of 8.6-9.1 ppm. The ketone functional groups were also confirmed via ${ }^{13} \mathrm{C}$ NMR analysis with low-field resonances of 194.5 and $199.3 \mathrm{ppm}$ for the carbonyl carbons attached to the $\beta$ and meso carbons, respectively. The diazepinefused porphyrin $\mathbf{4 b}$ exhibits a slight difference in chemical shifts for the $\beta$-protons, typical of fused moieties, with the two closest to the fused ring occurring as singlets with the highest field strength in the $\beta$-region. The structure was confirmed by HRMS, with a parent ion of $m / z=864.2222$ (calculated for $\left[\mathrm{C}_{54} \mathrm{H}_{36} \mathrm{~N}_{6} \mathrm{O}_{2} \mathrm{Zn}\right]: 864.2191$ ), and also the loss of signals at 194 and 198 ppm in ${ }^{13} \mathrm{C}$ NMR analysis for the carbonyl carbons. 

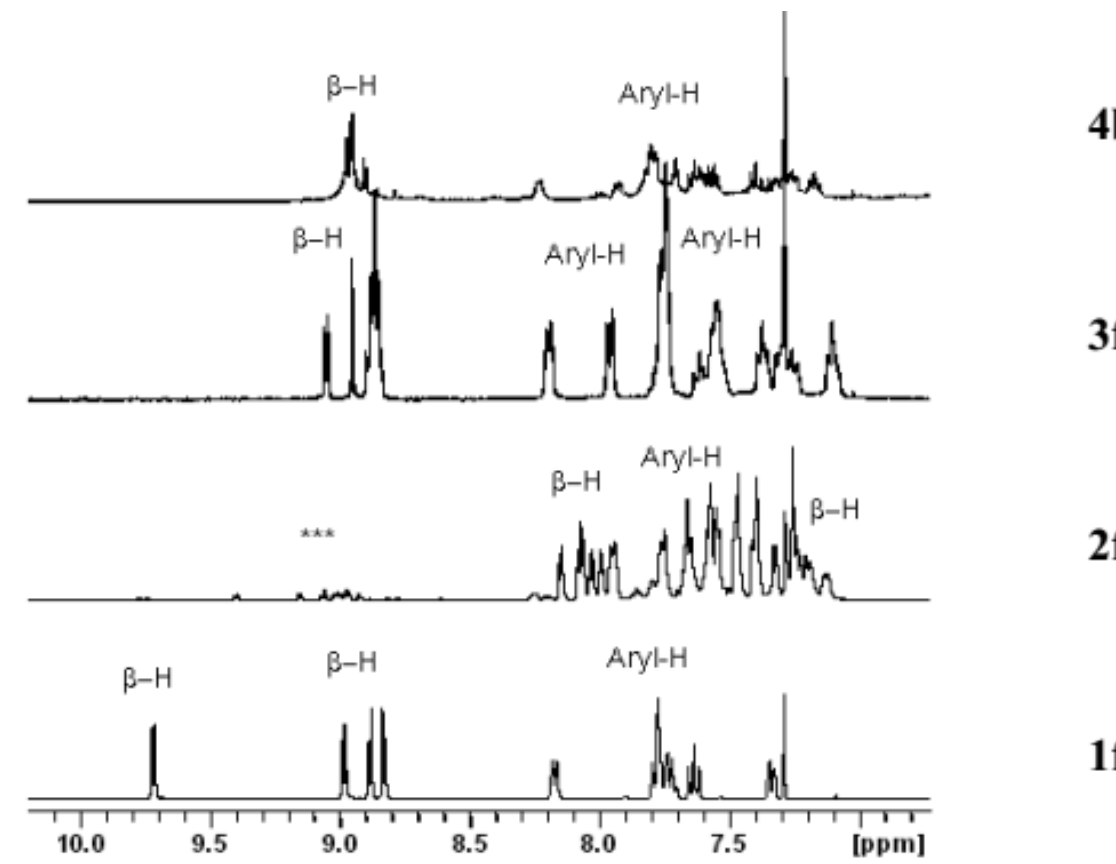

Fig. 3. ${ }^{1} \mathrm{H}$ NMR (400 MHz) spectra of 1f, $\mathbf{2 f}$, 3f, and $\mathbf{4 b}$ in $\mathrm{CDCl}_{3}(* * *$ impurities, compound not isolated before ring-opening)

In parallel to cycloaddition reactions of monomers and the generation of diazepineporphyrinoids, we sought to apply the [3+2] annulation methodology to bromo bisporphyrins. Taking the directly linked porphyrin dimer $\mathbf{5}$, we were able to execute a double cycloaddition to form 6 (which is a mixture of rotamers) in excellent yield of 72 \%. This bis-dehydropurpurin has an interesting UV spectrum, although due to inevitable ring opening on oxidation to generate triply fused systems, these compounds were not used in further syntheses. Additionally, the methodology was applied to triply fused bromo dimers $\mathbf{7 a}$ and $\mathbf{7 b}$ (Scheme 4). Employing the bromo-dimer 7a [3+2] annulation reactions were attempted, but without success. The main fraction isolated was unreacted starting material, with no detection of annulated dimer 8a. This may be attributed to the insolubility of the starting material but further investigations are needed. Trying to overcome the solubility issues, dimer $\mathbf{7 b}$ was used, with alkyl and tolyl substituents. The 
reactivity was enhanced but the desired product $\mathbf{8 b}$ was only obtained in a yield of less than $5 \%$, and it co-eluted with debrominated starting material. Also observed was the ring-opened derivative of $\mathbf{8 b}$, which may have formed during purification when exposed to to the air or due to the presence of trace oxidants in the starting material. The products formed were only characterized by HRMS with the ring-opened dimer showing a parent ion peak at $m / z=1342.3580$ (calculated for $\left[\mathrm{C}_{84} \mathrm{H}_{62} \mathrm{~N}_{8} \mathrm{O}_{2} \mathrm{Zn}_{2}\right]$ : 1342.3579).
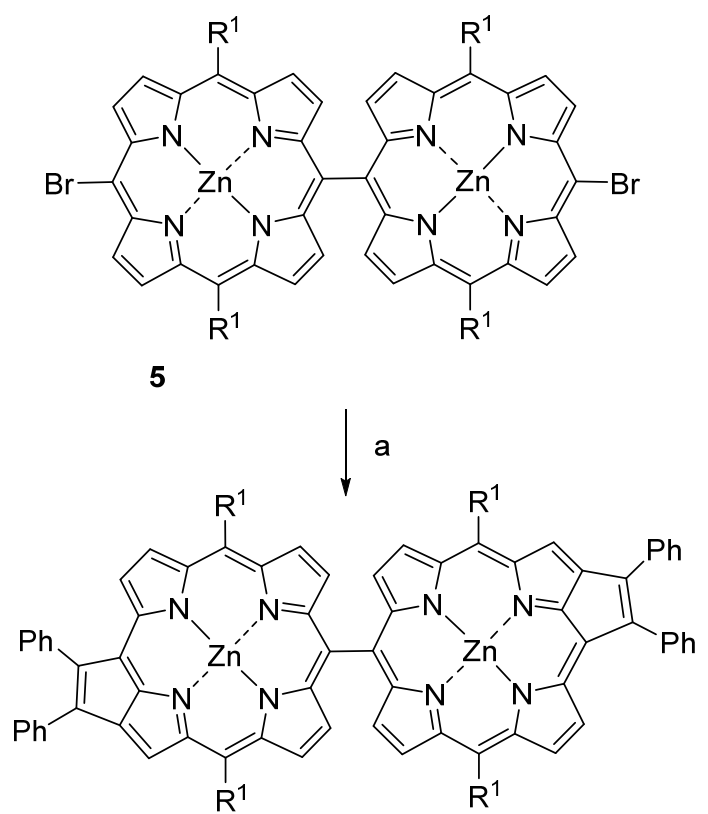

6: $\mathrm{R}^{1}=(3-\mathrm{OMe}) \mathrm{C}_{6} \mathrm{H}_{4}(72 \%)$

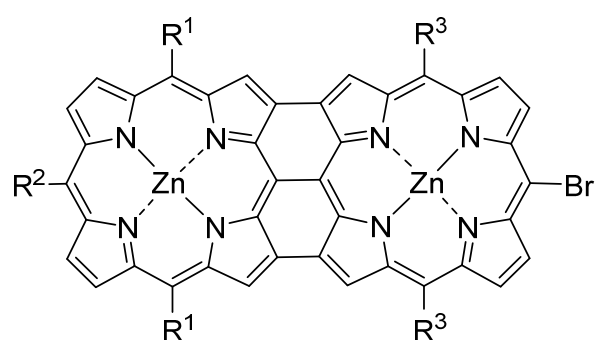

7a: $\mathrm{R}^{1}=\mathrm{Ph}, \mathrm{R}^{2}=(3-\mathrm{OMe}) \mathrm{C}_{6} \mathrm{H}_{4}$

7b: $\mathrm{R}^{1}=1$-Ethylpropyl, $\mathrm{R}^{2}=$ Tolyl

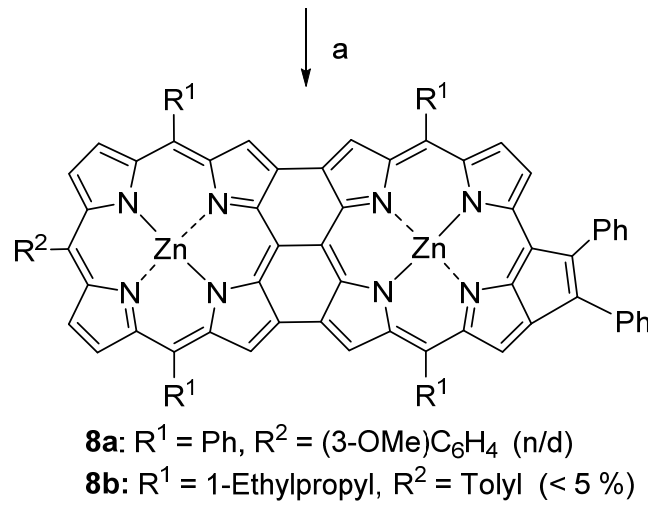

+ ring-opened products

Scheme 4. Synthesis of directly linked bis-dehydropurpurins 6a and fused derivatives $\mathbf{8 a}$ and 8b. Reagents and conditions: diphenylacetylene (1.5-3 eq. $), \mathrm{Pd}_{2}(\mathrm{dba})_{3}(5 \%),(o-$ $\mathrm{Tol})_{3} \mathrm{P}(0.2$ eq. $)$, toluene, $N, N$-dicyclohexylmethylamine $(5-10$ eq. $), 120^{\circ} \mathrm{C}, 24 \mathrm{~h}$.

Additionally, using the alkynyl linked dimer $\mathbf{9}$ as the internal alkyne source, the $[3+2]$ methodology with bromo-porphyrin 10 was employed to generate dehydropurpurin trimer 11. Although multiple attempts were carried out, $\mathbf{1 1}$ could only be isolated in a yield of $2 \%$ and only be identified via HRMS (Scheme 5). Here, lengthening the linker, 
for example to a diphenylacetylene, between the porphyrin units may help improve the reaction as the steric hindrance in the cycloaddition would be minimized.

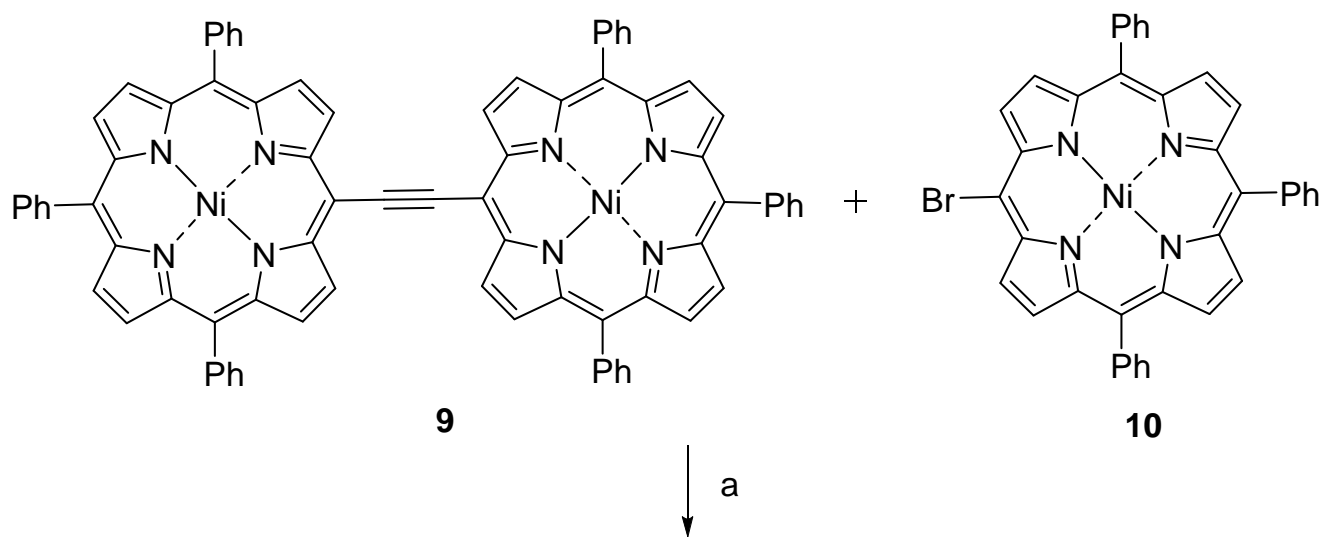

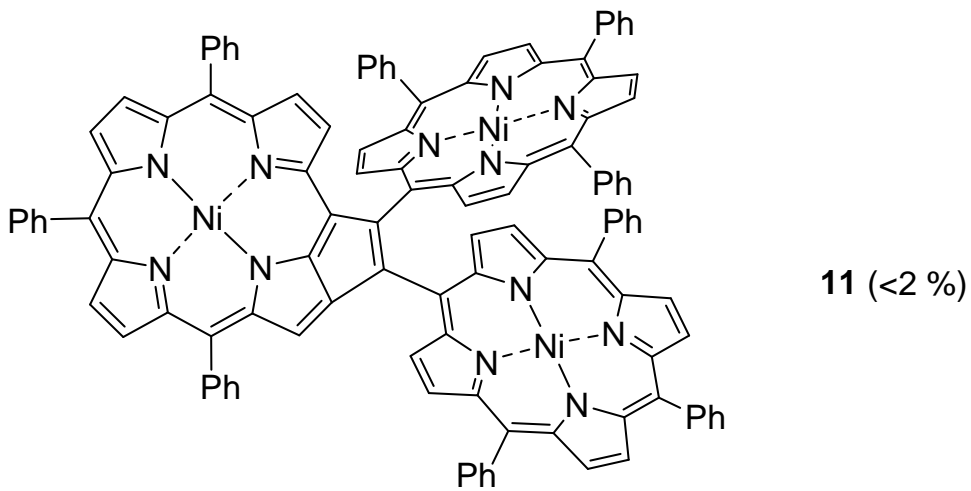

Scheme 5. Synthesis of porphyrin trimer 11. Reagents and conditions: a) 9 (1.5 eq.), 10 (1 eq.) $\mathrm{Pd}_{2}(\mathrm{dba})_{3}\left(0.2\right.$ eq.), $(o-\mathrm{Tol})_{3} \mathrm{P}(0.2$ eq. $)$, toluene, $N, N$-dicyclohexylmethylamine (510 eq.), $120^{\circ} \mathrm{C}, 24 \mathrm{~h}$.

In conclusion, diazepine-fused porphyrinoids were synthesized in moderate yields from 1,5-diketone precursors. These materials display bathochromic shifts in their absorption profiles. Additionally, the $[3+2]$ annulation methodology was applied to singly and triply linked porphyrin dimers. Future work will involve the synthesis of other fused hetero-aromatic moieties at the porphyrin periphery via similar principles and larger nitrogen heterocyclic derivatives, and also their incorporation into oligomeric porphyrins. 


\section{Experimental}

\section{General methods}

All commercial chemicals used were of analytical grade and were supplied by Sigma Aldrich, Frontier Scientific, Inc. and Tokyo Chemical Industry (TCI) and used without further purification unless otherwise stated. ${ }^{1} \mathrm{H}$ and ${ }^{13} \mathrm{C}$ NMR spectra were recorded on a Bruker DPX 400 and Agilent 400 (400 MHz for ${ }^{1} \mathrm{H}$ NMR; $100.6 \mathrm{MHz}$ for

${ }^{13} \mathrm{C}$ NMR) and/or Bruker AV 600 instrument (600 MHz for ${ }^{1} \mathrm{H}$ NMR; $150.9 \mathrm{MHz}$ for ${ }^{13} \mathrm{C}$ NMR). Chemical shifts are reported in ppm and locked on residual solvent peaks. The assignment of signals was confirmed by 2D spectra (COSY, HSQC) except for those porphyrins with low solubility. UV/Vis absorption measurements were performed with a Shimadzu MultiSpec-1501 instrument. Microwave reactions were carried out in a CEM Discover $600 \mathrm{~W}$ microwave reactor. HRMS spectra were measured on MaldiQ-Tof Premier Micromass and Micromass/Waters Corp. USA liquid chromatography time-offlight spectrometers equipped with an electrospray ionisation source (ESI). Melting points were acquired on a Stuart SMP-10 melting point apparatus and are uncorrected. Thin layer chromatography (TLC) was performed on silica gel 60 (fluorescence indicator $\mathrm{F}_{254}$; Merck) pre-coated aluminum sheets. Flash chromatography was carried out using Fluka Silica Gel 60 (230-400 mesh).

Porphyrins 1a-f [13,21], $\mathbf{9}$ and $\mathbf{1 0}$ [13] were synthesized according to previously reported methods [22].

\section{[3,5-Dibenzoyl-10,20-bis(4-methylphenyl)porphyrinato]zinc(II) (3a)}

Porphyrin 1a (200 mg, $0.32 \mathrm{mmol})$, diphenylacetylene $(84 \mathrm{mg}, 0.48 \mathrm{mmol})$ and $(o-$ Tol) $)_{3} \mathrm{P}(19 \mathrm{mg}, 0.06 \mathrm{mmol})$ were dried under a pressure of $10^{-2} \mathrm{mbar}$ in a $25 \mathrm{~mL}$ Schlenk tube before being used. Toluene $(5 \mathrm{~mL})$ was added under argon. The mixture was then subjected to three freeze-pump-thaw cycles to degas the solution. The reaction was protected from light for the next steps. $\operatorname{Pd}_{2}(\mathrm{dba})_{3}(15 \mathrm{mg}, 0.02 \mathrm{mmol})$ and $N, N$ dicyclohexylmethylamine $(0.35 \mathrm{~mL}, 1.65 \mathrm{mmol})$ were then added to the mixture which was then heated at $110{ }^{\circ} \mathrm{C}$ for $24 \mathrm{~h}$. Upon reaction completion, the solvent was removed under reduced pressure. The product was filtered through silica using $\mathrm{CH}_{2} \mathrm{Cl}_{2}$ as eluent 
and the solvent removed to obtain the ring-closed compound 2a. The product was then dissolved in $\mathrm{CH}_{2} \mathrm{Cl}_{2}(16 \mathrm{~L})$ and exposed to light for $72 \mathrm{~h}$ to obtain the ring-opened compound 3a. Yield: $176 \mathrm{mg}(0.23 \mathrm{mmol}, 72 \%)$ - M. p. $>300{ }^{\circ} \mathrm{C}$. - ${ }^{1} \mathrm{H}$ NMR $(400 \mathrm{MHz}$, $\left.\mathrm{CDCl}_{3}\right): \delta=2.67\left(\mathrm{~s}, 3 \mathrm{H}\right.$, tolyl- $\left.\mathrm{CH}_{3}\right), 2.74(\mathrm{~s}, 3 \mathrm{H}$, tolyl-CH$), 7.11-7.13(\mathrm{~m}, 2 \mathrm{H}, \mathrm{Ph}-H)$, 7.37 (t, $J=8.0 \mathrm{~Hz}, 2 \mathrm{H}, \mathrm{Ph}-H), 7.50-7.54\left(\mathrm{~m}, 6 \mathrm{H}, \mathrm{C}_{6} \mathrm{H}_{4} / \mathrm{Ph}-H\right), 7.59$ (d, $J=7.6 \mathrm{~Hz}, 2 \mathrm{H}$, $\left.\mathrm{C}_{6} \mathrm{H}_{4}-H\right), 7.83-7.85(\mathrm{~m}, 2 \mathrm{H}, \mathrm{Ph}-H), 8.08$ (d, $\left.J=7.6 \mathrm{~Hz}, 4 \mathrm{H}, \mathrm{C}_{6} \mathrm{H}_{4}-H\right), 8.91-8.96(\mathrm{~m}, 3 \mathrm{H}$, $\left.H_{\beta}\right), 9.09-9.11\left(\mathrm{~m}, 2 \mathrm{H}, H_{\beta}\right), 9.38-9.40\left(\mathrm{~m}, 2 \mathrm{H}, H_{\beta}\right), 10.27 \mathrm{ppm}\left(\mathrm{s}, 1 \mathrm{H}, H_{\text {meso }}\right) .-{ }^{13} \mathrm{C} \mathrm{NMR}$ $\left(100 \mathrm{MHz}, \mathrm{CDCl}_{3}\right): \delta=29.8,107.6,121.0,122.6,127.3,127.8,128.7,130.2,131.9$, $132.3,132.9,134.3,135.3,137.3,138.0,139.1,141.2$, 144.8, 138.4, 150.1, 150.6, 151.1, 151.8, 194.2, 198.7 ppm. - UV/Vis $\left(\mathrm{CH}_{2} \mathrm{Cl}_{2}\right): \lambda_{\max }(\log \varepsilon)=424$ (5.14), 550 (3.92), 590 nm (3.78). - HRMS (MALDI): $m / z=760.1807$ (calcd. 760.1817 for $\left[\mathrm{C}_{48} \mathrm{H}_{32} \mathrm{~N}_{4} \mathrm{O}_{2} \mathrm{Zn}\right]$ ).

\section{[3,5-Dibenzoyl-10,20-bis(4-methylphenyl)-15-phenyl-porphyrinato]zinc(II) (3b)}

Porphyrin $1 \mathbf{b}(200 \mathrm{mg}, 0.28 \mathrm{mmol})$, diphenylacetylene $(76 \mathrm{mg}, 0.43 \mathrm{mmol})$ and (oTol) $)_{3} \mathrm{P}(17 \mathrm{mg}, 0.06 \mathrm{mmol})$ were dried under a pressure of $10^{-2} \mathrm{mbar}$ before being used. Toluene $(5 \mathrm{~mL})$ was added under argon. The mixture was then subjected to three freezepump-thaw cycles. $\operatorname{Pd}_{2}(\mathrm{dba})_{3}(13 \mathrm{mg}, 0.01 \mathrm{mmol})$ and $N, N$-dicyclohexylmethylamine $(0.29 \mathrm{~mL}, 1.40 \mathrm{mmol})$ were then added to the mixture which was then heated at $110{ }^{\circ} \mathrm{C}$ for $24 \mathrm{~h}$. Upon reaction completion, the solvents were removed in vacuo. The residue was filtered through a short plug of silica gel using $\mathrm{CH}_{2} \mathrm{Cl}_{2}$ as eluent, and the solvent was removed in vacuo to obtain the ring-closed compound $\mathbf{2 b}$. This was then dissolved in $\mathrm{CH}_{2} \mathrm{Cl}_{2}(14 \mathrm{~L})$ and exposed to light for $72 \mathrm{~h}$ to obtain the ring-opened compound $\mathbf{3 b}$. Yield: $124 \mathrm{mg}$ (0.15 mmol, $52 \%$ ). M. p. $>300{ }^{\circ} \mathrm{C}$. - ${ }^{1} \mathrm{H}$ NMR $\left(400 \mathrm{MHz}, \mathrm{CDCl}_{3}\right): \delta=$ $2.63\left(\mathrm{~s}, 3 \mathrm{H}\right.$, tolyl- $\left.\mathrm{CH}_{3}\right), 2.70\left(\mathrm{~s}, 3 \mathrm{H}\right.$, tolyl- $\left.\mathrm{CH}_{3}\right), 7.08(\mathrm{t}, J=7.8 \mathrm{~Hz}, 2 \mathrm{H}, \mathrm{Ph}-H), 7.25$ (d, $J$ $=7.3 \mathrm{~Hz}, 1 \mathrm{H}, \mathrm{Ph}-H), 7.36(\mathrm{t}, J=7.8 \mathrm{~Hz}, 2 \mathrm{H}, \mathrm{Ph}-H), 7.46\left(\mathrm{~d}, J=7.8 \mathrm{~Hz}, 2 \mathrm{H}, \mathrm{C}_{6} \mathrm{H}_{4}-H\right)$, 7.51-7.58 (m, 6H, Ph- $H$ ), 7.73-7.76 (m, 4H, $\left.\mathrm{C}_{6} \mathrm{H}_{4} / \mathrm{Ph}-H\right), 7.94\left(\mathrm{~d}, J=7.8 \mathrm{~Hz}, 2 \mathrm{H}, \mathrm{C}_{6} \mathrm{H}_{4}-\right.$ H) $8.04\left(\mathrm{~m}, 4 \mathrm{H}, \mathrm{C}_{6} \mathrm{H}_{4} / \mathrm{Ph}-H\right), 8.16-8.20\left(\mathrm{~m}, 2 \mathrm{H}, H_{\beta}\right), 8.83-8.86\left(\mathrm{~m}, 3 \mathrm{H}, H_{\beta}\right), 8.92(\mathrm{~s}, 1 \mathrm{H}$, $\left.H_{\beta}\right), 9.04 \mathrm{ppm}\left(\mathrm{d}, J=4.6 \mathrm{~Hz}, 2 \mathrm{H}, H_{\beta}\right) .-{ }^{13} \mathrm{C} \mathrm{NMR}\left(100 \mathrm{MHz}, \mathrm{CDCl}_{3}\right): \delta=29.7,116.5$, $121.2,122.8,123.0,126.4,127.2,127.4,127.6,128.0,128.2,128.9,129.8,130.5,130.9$, 131.5, 131.6, 132.0, 132.1, 132.5, 132.6, 132.9, 134.5, 137.0, 137.2, 138.5, 139.7, 139.9, 141.6, 143.0, 143.3, 145.8, 146.0, 150.2, 150.5, 150.6, 151.3, 151.8, 194.8, 199.4 ppm. - 
UV/Vis $\left(\mathrm{CH}_{2} \mathrm{Cl}_{2}\right): \lambda_{\max }(\log \varepsilon)=429$ (5.38), 556 (4.09), $597 \mathrm{~nm}$ (3.78). - HRMS (MALDI): $m / z=836.2161$ (calcd. 836.2130 for $\left[\mathrm{C}_{54} \mathrm{H}_{36} \mathrm{~N}_{4} \mathrm{O}_{2} \mathrm{Zn}\right]$ ).

\section{[3,5-Dibenzoyl-10,15,20-triphenylporphyrinato]zinc(II) (3c)}

Zinc bromoporphyrin 1c $(202 \mathrm{mg}, 0.30 \mathrm{mmol})$ and diphenylacetylene $(79 \mathrm{mg}, 0.44$ mmol) were added to a $25 \mathrm{~mL}$ Schlenk flask and were dried under a pressure of $10^{-2} \mathrm{mbar}$ for $20 \mathrm{~min}$. Anhydrous toluene $(10 \mathrm{~mL})$ and $(o-T o l)_{3} \mathrm{P}(18 \mathrm{mg}, 0.06 \mathrm{mmol})$ were added, and the solution was degassed by three freeze-pump-thaw cycles. $\operatorname{Pd}_{2}(\mathrm{dba})_{3}(14 \mathrm{mg}, 0.02$ mmol, $)$ and $N, N$-dicyclohexylmethylamine $(0.32 \mathrm{~mL}, 0.15 \mathrm{mmol})$ were added, and the flask was sealed and the mixture stirred at $120^{\circ} \mathrm{C}$ for $24 \mathrm{~h}$ in the dark. The solvent was evaporated under reduced pressure and the crude reaction mixture was purified by column chromatography in the dark using $n$-hexane/ethyl acetate $=20: 1(v / v)$. The solvents were removed in vacuo, to yield the desired product as the second fraction 2c (brown spot). $R_{\mathrm{f}}=0.22$ ( $n$-hexane/ethyl acetate $\left.=9: 1, v / v\right) .-\mathrm{UV} / \mathrm{Vis}\left(\mathrm{CH}_{2} \mathrm{Cl}_{2}\right): \lambda_{\max }=$ 401, 413, 490, 624, 684 nm. - HRMS (MALDI): $m / z=776.1896$ (calcd. 776.1918 for $\left.\left[\mathrm{C}_{52} \mathrm{H}_{32} \mathrm{~N}_{4} \mathrm{Zn}\right]\right)$. Crude 2c was dissolved in $\mathrm{CHCl}_{3}(4-5 \mathrm{~L})$ and was allowed to stir exposed to ambient light and air for $48 \mathrm{~h}$. The solvent was removed in vacuo and 3c was isolated as a green powder $(204 \mathrm{mg}, 0.25 \mathrm{mmol}, 85 \%)$. M. p. $>300{ }^{\circ} \mathrm{C}$. $-R_{\mathrm{f}}=0.33(n-$ hexane/ethyl acetate $=9: 1, v / v) .{ }^{1} \mathrm{H}$ NMR $\left(400 \mathrm{MHz}, \mathrm{CDCl}_{3}\right): \delta=7.20(\mathrm{t}, J=7.8 \mathrm{~Hz}$, 2H, Ph- $H$ ), 7.41 (m, 3H, Ph- $H$ ), 7.57 (t, $J=7.5$ Hz, 1H, Ph- $H), 7.72-7.78$ (m, 9H, Ph- $H$ ), $7.95(\mathrm{~d}, J=7.6 \mathrm{~Hz}, 2 \mathrm{H}, \mathrm{Ph}-H), 8.20(\mathrm{~d}, J=6.2 \mathrm{~Hz}, 4 \mathrm{H}, \mathrm{Ph}-H), 8.24$ (d, $J=6.2 \mathrm{~Hz}, 2 \mathrm{H}$; $\mathrm{Ph}-H), 8.88\left(\mathrm{~d}, J=4.8 \mathrm{~Hz}, 1 \mathrm{H} ; H_{\beta}\right), 8.94-8.98\left(\mathrm{~m}, 5 \mathrm{H} ; H_{\beta}\right), 9.01 \mathrm{ppm}(\mathrm{d}, J=4.8 \mathrm{~Hz}, 1 \mathrm{H}$, $\left.H_{\beta}\right) .-{ }^{13} \mathrm{C} \mathrm{NMR}\left(100 \mathrm{MHz}, \mathrm{CDCl}_{3}\right): \delta=121.8,123.1,123.3,126.6,126.7,127.7,127.8$, $128.1,130.5,131.6,131.8,132.4,132.5,132.6,132.9,133.0,134.4,134.4,134.4,135.6$, $138.2,141.8,142.1,142.2,142.9,149.0,150.6,150.8,151.8,194.4(\mathrm{C}=\mathrm{O}), 198.8 \mathrm{ppm}$ $(\mathrm{C}=\mathrm{O}) .-\mathrm{UV} / \mathrm{Vis}\left(\mathrm{CH}_{2} \mathrm{Cl}_{2}\right): \lambda_{\max }(\log \varepsilon)=429$ (5.02), 555 (3.77), $596 \mathrm{~nm}$ (3.46). HRMS (MALDI): $m / z=808.1826$ (calcd. 808.1817 for $\left[\mathrm{C}_{52} \mathrm{H}_{32} \mathrm{~N}_{4} \mathrm{O}_{2} \mathrm{Zn}\right]$ )

\section{[3,5-Dibenzoyl-10,20-bis(3-methoxyphenylporphyrinato]zinc(II) (3d)}

Bromoporphyrin 1d (25 mg, $0.04 \mathrm{mmol})$, diphenylacetylene (10 mg, $0.06 \mathrm{mmol})$ and $(o-\mathrm{Tol}){ }_{3} \mathrm{P}(3 \mathrm{mg}, 0.01 \mathrm{mmol})$ were added to a $25 \mathrm{~mL}$ Schlenk tube and dried under a 
pressure of $10^{-2} \mathrm{mbar}$ for $20 \mathrm{~min}$. Toluene $(3 \mathrm{~mL})$ was added, and the solution was degassed via three freeze-pump-thaw cycles. $\mathrm{Pd}_{2}(\mathrm{dba})_{3}(2 \mathrm{mg}, 0.002 \mathrm{mmol})$ and $N, N-$ dicyclohexylmethylamine (37 $\mathrm{mg}, 0.17 \mathrm{mmol}$ ) were added, and the reaction mixture was heated to $110^{\circ} \mathrm{C}$ and stirred at this temperature for $19 \mathrm{~h}$, shielded from ambient light. The reaction mixture was filtered through a short plug of silica using $\mathrm{CH}_{2} \mathrm{Cl}_{2}$ as eluent. Solvents were removed to yield a crude dark-orange solid containing $\mathbf{2 d}$ confirmed by UV/Vis and HRMS analysis: UV/Vis $\left(\mathrm{CH}_{2} \mathrm{Cl}_{2}\right): \lambda_{\max }=414,537$, and $571 \mathrm{~nm}$. - HRMS (MALDI): $m / z=760.1853$ (calcd. 760.1817 for $\left[\mathrm{C}_{48} \mathrm{H}_{32} \mathrm{~N}_{4} \mathrm{O}_{2} \mathrm{Zn}\right]$ ). Porphyrin 2d (25 mg) was dissolved in $\mathrm{CHCl}_{3}(3 \mathrm{~L})$ and stirred open to the air at room temperature, for $20 \mathrm{~h}$. The transformation was monitored via UV/Vis analysis and upon completion, solvents were removed in vacuo, and the residue was purified via a short column of silica $\left(\mathrm{CH}_{2} \mathrm{Cl}_{2}\right.$ : hexane, 4:1, v/v). Solvents were removed to yield porphyrin 3c (24 mg, $0.03 \mathrm{mmol}, 80$ \%). M.p. $>300{ }^{\circ} \mathrm{C} .-R_{\mathrm{f}}=0.37(n$-hexane/EtOAc $=3: 1, v / v) .-{ }^{1} \mathrm{H}$ NMR $(400 \mathrm{MHz}$, $\left.\mathrm{CDCl}_{3}\right): \delta=3.91\left(\mathrm{~s}, 3 \mathrm{H}, \mathrm{OCH}_{3}\right), 3.96\left(\mathrm{~s}, 3 \mathrm{H}, \mathrm{OCH}_{3}\right), 7.04-7.08\left(\mathrm{t}, J=15.2 \mathrm{~Hz}, 2 \mathrm{H}, \mathrm{C}_{6} \mathrm{H}_{4}-\right.$ $H$ ), 7.24-7.27 (t, $\left.J=13.5 \mathrm{~Hz}, 2 \mathrm{H}, \mathrm{C}_{6} \mathrm{H}_{4}-H\right), 7.33$ (m, 4H, Ph- $H$ ), $7.49\left(\mathrm{~m}, 1 \mathrm{H}, \mathrm{C}_{6} \mathrm{H}_{4}-H\right)$, 7.59 (m, 1H, Ph- $H$ ), 7.63 (m, 2H, $\left.\left.\mathrm{C}_{6} \mathrm{H}_{4}-H\right),-H\right), 7.74$ (m, 4H, Ph- $H$ ), 7.79 (m, 2H, Ph- $H$ ), $8.91\left(\mathrm{~m}, 3 \mathrm{H}, H_{\beta}\right), 9.09\left(\mathrm{~m}, 2 \mathrm{H}, H_{\beta}\right), 9.38\left(\mathrm{~m}, 2 \mathrm{H}, H_{\beta}\right), 10.28 \mathrm{ppm}\left(\mathrm{s}, 1 \mathrm{H}, \mathrm{H}_{\text {meso }}\right) .{ }^{13} \mathrm{C}$ NMR (100 MHz, $\left.\mathrm{CDCl}_{3}\right): \delta=55.4,55.5,108.0,113.5,120.5,122.3,127.4,127.6,127.7$, 128.0, 130.4, 131.6, 132.2, 132.4, 132.7, 132.8, 135.5, 138.0, 141.1, 142.8, 143.3, 143.6, $144.2,144.9,148.8,150.3,150.4,151.0,151.8,157.8,157.9,194.4(\mathrm{C}=\mathrm{O}), 198.9$ ppm $(\mathrm{C}=\mathrm{O})$. - UV/Vis $\left(\mathrm{CH}_{2} \mathrm{Cl}_{2}\right): \lambda_{\max }(\log \varepsilon)=415$ (5.47), 479 (4.15) $543 \mathrm{~nm}$ (4.15). - HRMS (MALDI): $m / z=792.1732$ (calcd. 792.1715 for $\left[\mathrm{C}_{48} \mathrm{H}_{32} \mathrm{~N}_{4} \mathrm{O}_{4} \mathrm{Zn}\right]$ ).

\section{[3,5-Dibenzoyl-10,15,20-tris(3-methoxyphenylporphyrinato]zinc(II) (3e)}

Porphyrin 1e $(200 \mathrm{mg}, 0.26 \mathrm{mmol})$, diphenylacetylene $(69 \mathrm{mg}, 0.39 \mathrm{mmol})$ and $(o-$ Tol $)_{3} \mathrm{P}(16 \mathrm{mg}, 0.05 \mathrm{mmol})$ were dried under high vacuum for $1 \mathrm{~h}$. Dry toluene $(15 \mathrm{~mL})$ was added under argon. The solution was degassed via three freeze-pump-thaw cycles. The Schlenk tube was shielded from light. $\operatorname{Pd}_{2}(\mathrm{dba})_{3}(12 \mathrm{mg}, 0.01 \mathrm{mmol})$ and the $N, N$ dicyclohexylmethylamine $(0.28 \mathrm{~mL}, 1.30 \mathrm{mmol})$ were added to the Schlenk tube, and the reaction mixture was heated at $110{ }^{\circ} \mathrm{C}$ for $24 \mathrm{~h}$. The solvent was removed in vacuo, and the residue was filtered through silica gel using a mixture of $\mathrm{CH}_{2} \mathrm{Cl}_{2} /$ hexane $(2: 1, v / v)$. 
The solvents were removed to obtain the ring-closed product $2 \mathbf{e}$. The product was then dissolved in of $\mathrm{CH}_{2} \mathrm{Cl}_{2}(18 \mathrm{~L})$ and exposed to light for at $24 \mathrm{~h}$. The ring opening reaction was followed by UV/Vis analysis, and upon completion, the solvent was removed under reduced pressure. A short column chromatography was then performed using a mixture of $\mathrm{CH}_{2} \mathrm{Cl}_{2}$ /hexane. Yield: $91 \mathrm{mg}(0.10 \mathrm{mmol}, 39 \%)$. M. p. $>300{ }^{\circ} \mathrm{C}$. - ${ }^{1} \mathrm{H}$ NMR $(400$ $\left.\mathrm{MHz}, \mathrm{CDCl}_{3}\right): \delta=3.91\left(\mathrm{~s}, 3 \mathrm{H}, \mathrm{OCH}_{3}\right), 3.94\left(\mathrm{~s}, 3 \mathrm{H}, \mathrm{OCH}_{3}\right), 3.98\left(\mathrm{~s}, 3 \mathrm{H}, \mathrm{OCH}_{3}\right), 7.14(\mathrm{t}, J$ $\left.=7.6 \mathrm{~Hz}, 2 \mathrm{H}, \mathrm{C}_{6} \mathrm{H}_{4}-H\right), 7.23\left(\mathrm{~m}, 1 \mathrm{H}, \mathrm{C}_{6} \mathrm{H}_{4}-H\right), 7.32-7.37(\mathrm{~m}, 5 \mathrm{H}, \mathrm{Ph}-H), 7.52-7.70(\mathrm{~m}$, $\left.8 \mathrm{H}, \mathrm{C}_{6} \mathrm{H}_{4} / \mathrm{Ph}-H\right)$, 7.76-7.83 (m, 6H, $\left.\mathrm{C}_{6} \mathrm{H}_{4}-H / \mathrm{Ph}-\mathrm{H}\right), 8.87-9.00 \mathrm{ppm}\left(\mathrm{m}, 7 \mathrm{H}, H_{\beta}\right)$ ppm. ${ }^{13} \mathrm{C}$ NMR (100 MHz, $\left.\mathrm{CDCl}_{3}\right): \delta=55.4,55.5,55.5,113.5,113.7,120.4,121.4,122.8$, $122.9,127.4,127.5,127.6,127.7,128.0,130.4,131.5,131.7,132.4,132.5,132.9,133.0$, 135.6, 138.1, 141.5, 142.8, 143.4, 143.6, 143.7, 145.5, 146.0, 148.9, 150.4, 150.5, 150.7, $150.9,151.7,157.7,157.9,194.3,198.8$ ppm. - UV/Vis $\left(\mathrm{CH}_{2} \mathrm{Cl}_{2}\right): \lambda_{\max }(\log \varepsilon)=428$ (5.36), 554 (4.14), $594 \mathrm{~nm}$ (3.82). - HRMS (MALDI): $m / z=898.2118$ (calcd. 898.2134 for $\left.\left[\mathrm{C}_{55} \mathrm{H}_{38} \mathrm{~N}_{4} \mathrm{O}_{5} \mathrm{Zn}\right]\right)$.

\section{[3,5-Dibenzoyl-10,20-bis(3-methoxyphenyl)-15-phenylporphyrinato]zinc(II) (3f)}

Bromoporphyrin 1f (70 mg, $0.09 \mathrm{mmol})$, diphenylacetylene (25 mg, $0.14 \mathrm{mmol})$ and $(o-\mathrm{Tol})_{3} \mathrm{P}(6 \mathrm{mg}, 0.02 \mathrm{mmol})$ were charged to a $10 \mathrm{~mL}$ Schlenk tube and dried under high vacuum for $20 \mathrm{~min}$. Toluene $(3 \mathrm{~mL})$ was added and the solution was degassed via three freeze-pump-thaw cycles. $\quad \mathrm{Pd}_{2}(\mathrm{dba})_{3} \quad(4 \quad \mathrm{mg}, \quad 0.01 \quad \mathrm{mmol})$ and $N, N$ dicyclohexylmethylamine ( $85 \mathrm{mg}, 0.47 \mathrm{mmol}$ ) were added, and the reaction was heated to $120{ }^{\circ} \mathrm{C}$ and stirred at this temperature for $24 \mathrm{~h}$, shielded from ambient light. The reaction mixture was filtered through a short plug of silica using $\mathrm{CH}_{2} \mathrm{Cl}_{2}$ as eluent. The solvent was removed to yield a dark-orange solid 2f, confirmed by UV/Vis and HRMS analysis: UV/Vis $\left(\mathrm{CH}_{2} \mathrm{Cl}_{2}\right): \lambda_{\max }(\log \varepsilon)=416$ (5.33), 489 (5.18), 619 (4.02) nm; HRMS (MALDI) $m / z=836.2136$ (calcd. 836.2130 for $\left[\mathrm{C}_{54} \mathrm{H}_{36} \mathrm{~N}_{4} \mathrm{O}_{2} \mathrm{Zn}\right]$ ). A solution of crude $\mathbf{2 f}$ $(65 \mathrm{mg})$ in $\mathrm{CHCl}_{3}(3 \mathrm{~L})$ was stirred, open to the air at room temperature, for $20 \mathrm{~h}$. The transformation was monitored via $\mathrm{UV} / \mathrm{V}$ is analysis until the purpurin had changed to porphyrin 3f. Upon completion, solvents were removed in vacuo, and the residue was purified via a short column of silica $\left(\mathrm{CH}_{2} \mathrm{Cl}_{2} /\right.$ hexane, $\left.4: 1, v / v\right)$ to give two fractions, the second of which contained 3f. The solvents were removed to yield porphyrin $3 \mathbf{f}(62 \mathrm{mg}$, 
0.07 mmol, $76 \%$ ). M. p. $>300{ }^{\circ} \mathrm{C} .-R_{\mathrm{f}}=0.32(n$-hexane/EtOAc $=3: 1, v / v) .-{ }^{1} \mathrm{H}$ NMR $\left(400 \mathrm{MHz}, \mathrm{CDCl}_{3}\right): \delta=3.97\left(\mathrm{~s}, 3 \mathrm{H}, \mathrm{OCH}_{3}\right), 3.99\left(\mathrm{~s}, 3 \mathrm{H}, \mathrm{OCH}_{3}\right), 7.10\left(\mathrm{~m}, 2 \mathrm{H}, \mathrm{C}_{6} \mathrm{H}_{4}-H\right)$, $7.25\left(\mathrm{~m}, 1 \mathrm{H}, \mathrm{C}_{6} \mathrm{H}_{4}-H\right), 7.37$ (m, 2H, Ph- $\left.H\right), 7.56\left(\mathrm{~m}, 4 \mathrm{H}, \mathrm{C}_{6} \mathrm{H}_{4}-H\right), 7.63$ (m, 2H, Ph- $H$ ), 7.75 (m, 7H, Ph-H), 7.97 (d, $J=7.9$ Hz, 2H, Ph- $H), 8.20$ (d, $J=8.0 \mathrm{~Hz}, 2 \mathrm{H}, \mathrm{Ph}-H), 8.87$ $\left(\mathrm{m}, 5 \mathrm{H}, H_{\beta}\right), 8.96\left(\mathrm{~d}, J=4.7 \mathrm{~Hz}, 1 \mathrm{H}, H_{\beta}\right), 9.08 \mathrm{ppm}\left(\mathrm{d}, J=4.7 \mathrm{~Hz}, 1 \mathrm{H}, H_{\beta}\right) .-{ }^{13} \mathrm{C} \mathrm{NMR}$ $\left(100 \mathrm{MHz}, \mathrm{CDCl}_{3}\right): \delta=55.4,55.5,113.1,113.2,120.6,120.9,122.5,122.9,123.1,123.4$, $126.4,127.1,127.2,127.5,127.6,127.8,128.0,130.5,131.5,131.7,132.0,132.1,132.6$, $132.7,132.8,134.4,135.2,135.5,135.7,135.9,141.8,142.9,143.3,143.9,144.2,145.7$, 145.8, 148.9, 149.1, 149.3, 150.2, 150.4, 150.6, 151.0, 151.5, 157.7, 157.8, 194.8, 199.3 ppm. - UV/Vis $\left(\mathrm{CH}_{2} \mathrm{Cl}_{2}\right): \lambda_{\max }(\log \varepsilon)=428$ (5.22), 553 (4.07), $596 \mathrm{~nm}$ (3.64). - HRMS (MALDI): $m / z=868.1988$ (calcd. 868.2028 for $\left[\mathrm{C}_{54} \mathrm{H}_{36} \mathrm{~N}_{4} \mathrm{O}_{4} \mathrm{Zn}\right]$ ).

[7,8-(6,9-Diphenyl)diazepine-10,20-bis(4-methylphenyl)porphyrinato]zinc(II) (4a)

Porphyrin 3a (50 mg, $0.07 \mathrm{mmol})$ and hydrazine hydrate $24 \%$ (0.3 mL, excess) were refluxed in acetic acid $(6 \mathrm{~mL})$ and toluene $(6 \mathrm{~mL})$ for $24 \mathrm{~h}$. The mixture was cooled before being washed using $\mathrm{CH}_{2} \mathrm{Cl}_{2}$ and water. The organic layer was dried with sodium sulfate, and after filtration the solvent was removed in vacuo. The residue was then purified by silica gel column chromatography using $\mathrm{CH}_{2} \mathrm{Cl}_{2} / \mathrm{EtOAc}(10: 1, v / v)$ as eluent. The targeted compound 4a was the third fraction. Yield: $4 \mathrm{mg}(0.005 \mathrm{mmol}, 8 \%)$. M. p. $>300{ }^{\circ} \mathrm{C}$. - ${ }^{1} \mathrm{H}$ NMR $\left(400 \mathrm{MHz}, \mathrm{CDCl}_{3}\right): \delta=2.64$ (s, 6H, $\left.\mathrm{C}_{6} \mathrm{H}_{4}-H\right), 7.40-7.49(\mathrm{~m}, 6 \mathrm{H}$, aryl- $H), 7.53-7.56(\mathrm{~m}, 4 \mathrm{H}$, aryl- $H), 7.75-7.83(\mathrm{~m}, 4 \mathrm{H}$, tolyl- $H), 7.99-8.02(\mathrm{~m}, 2 \mathrm{H}$, tolyl$H), 8.09-8.13(\mathrm{~m}, 2 \mathrm{H}$, tolyl- $H), 8.45-8.46\left(\mathrm{~m}, 2 \mathrm{H}, H_{\beta}\right), 8.94\left(\mathrm{~m}, 3 \mathrm{H}, H_{\beta}\right), 9.28-9.31(\mathrm{~m}$, $\left.2 \mathrm{H}, H_{\beta}\right), 9.88 \mathrm{ppm}\left(\mathrm{s}, 1 \mathrm{H}, H_{\text {meso }}\right) .{ }^{13} \mathrm{C} \mathrm{NMR}\left(100 \mathrm{MHz}, \mathrm{CDCl}_{3}\right): \delta=29.5,100.2,117.8$, $121.9,127.2$, 127.5, 127.7, 129.7, 130.8, 131.1, 131.5, 131.7, 131.9, 132.2, 132.3, 132.6, $132.7,132.8,132.9,133.1,133.5,133.7,134.2,134.3,134.4,146.1,152.2,152.6,154.6$, 155.5, 158.5, 162.5, 167.6 ppm. - UV/Vis $\left(\mathrm{CH}_{2} \mathrm{Cl}_{2}\right): \lambda_{\max }=443$ (4.98), 574 (3.79), 608 nm (3.69). - HRMS (MALDI): $m / z=757.2066$ (calcd. 757.2058 for $\left[\mathrm{C}_{48} \mathrm{H}_{32} \mathrm{~N}_{6} \mathrm{Zn}\right]$ ).

[7,8-(6,9-Diphenyl)diazepine-5-phenyl-10,20-bis(4-methylphenyl)porphyrinato]zinc(II) (4b) 
Porphyrin $3 f(20 \mathrm{mg}, 0.02 \mathrm{mmol})$, hydrazine hydrate $(0.1 \mathrm{~mL})$ mmol, acetic acid (1 $\mathrm{mL})$ and toluene $(1 \mathrm{~mL})$ were placed in a $5 \mathrm{~mL}$ flask, and the mixture was irradiated under microwave conditions at $110{ }^{\circ} \mathrm{C}$ for $7 \mathrm{~min}$. After completion, the reaction mixture was allowed to cool and diluted with $\mathrm{CH}_{2} \mathrm{Cl}_{2}$. The solution washed with $\mathrm{H}_{2} \mathrm{O}(2 \times 10$ $\mathrm{mL}$ ), extracted with $\mathrm{CH}_{2} \mathrm{Cl}_{2}$, dried over $\mathrm{Na}_{2} \mathrm{SO}_{4}$ and filtered. Solvents were removed to yield a green solid which was redissolved in $\mathrm{CH}_{2} \mathrm{Cl}_{2}$ and filtered through a short plug of silica. The solvents were removed in vacuo to give a green solid of $\mathbf{4 b}(10 \mathrm{mg}, 0.01$ mmol, $49 \%)$. M. p. $>300{ }^{\circ} \mathrm{C} .-R_{\mathrm{f}}=0.27\left(\mathrm{CH}_{2} \mathrm{Cl}_{2} /\right.$ EtOAc $\left.10: 1, v / v\right) .-{ }^{1} \mathrm{H}$ NMR $(400$ $\left.\mathrm{MHz}, \mathrm{CDCl}_{3}\right): \delta=3.93\left(\mathrm{~s}, 3 \mathrm{H}, \mathrm{OCH}_{3}\right), 3.95\left(\mathrm{~s}, 3 \mathrm{H}, \mathrm{OCH}_{3}\right), 7.16-7.18(\mathrm{~d}, J=15.7 \mathrm{~Hz}$, $\left.2 \mathrm{H}, \mathrm{C}_{6} \mathrm{H}_{4}-H\right), 7.24-7.27$ (dd, $\left.J=11.0 \mathrm{~Hz}, 2 \mathrm{H}, \mathrm{C}_{6} \mathrm{H}_{4}-H\right), 7.35\left(\mathrm{~m}, 2 \mathrm{H}, \mathrm{C}_{6} \mathrm{H}_{4}-H\right), 7.38-7.42$ (t, $\left.J=15.5 \mathrm{~Hz}, 2 \mathrm{H}, \mathrm{C}_{6} \mathrm{H}_{4}-H\right), 7.55-7.58\left(\mathrm{t}, J=13.7 \mathrm{~Hz}, 2 \mathrm{H}, \mathrm{C}_{6} \mathrm{H}_{4}-H\right), 7.63(\mathrm{~m}, 2 \mathrm{H}, \mathrm{Ph}-$ $H), 7.75$ (m, 2H, Ph- $H), 7.82(\mathrm{~m}, 5 \mathrm{H}, \mathrm{Ph}-H), 7.93-7.94$ (d, $J=8.0 \mathrm{~Hz}, 2 \mathrm{H}, \mathrm{Ph}-H), 8.23$ $(\mathrm{m}, 2 \mathrm{H}, \mathrm{Ph}-H), 8.90-8.91\left(\mathrm{~d}, J=4.8 \mathrm{~Hz}, 2 \mathrm{H}, H_{\beta}\right), 8.96 \mathrm{ppm}\left(\mathrm{m}, 5 \mathrm{H}, H_{\beta}\right) .-{ }^{13} \mathrm{C}$ NMR $(100$ $\left.\mathrm{MHz}, \mathrm{CDCl}_{3}\right): \delta=55.4,55.5,113.5,113.7,120.4,122.8,123.2,126.7,127.4,127.5$, $127.8,128.1,129.3,130.5,130.9,132.4,132.5,132.9,134.3,135.6,138.2,141.7,142.3$, $142.9,143.4,143.5,145.6,146.0,149.0,150.4,150.6,150.8,150.9,151.6,157.8,157.9$ ppm. - UV/Vis $\left(\mathrm{CH}_{2} \mathrm{Cl}_{2}\right): \lambda_{\max }(\log \varepsilon)=428$ (5.01), 555 (3.95), $703 \mathrm{~nm}$ (3.80). - HRMS (MALDI): $m / z=864.2222$ (calcd. 864.2191 for $\left[\mathrm{C}_{54} \mathrm{H}_{36} \mathrm{~N}_{6} \mathrm{O}_{2} \mathrm{Zn}\right.$ ).

\section{[7,8-(6,9-Diphenyl)diazepine-10,20-bis(4-methylphenyl)porphyrinato]zinc(II) (4c)}

Porphyrin 3d $(56 \mathrm{mg}, 0.07 \mathrm{mmol})$ and hydrazine dihydrochloride $(70 \mathrm{mg}, 0.71$ mmol) were refluxed in EtOH $(15 \mathrm{~mL})$ for $24 \mathrm{~h}$. The mixture was cooled before being diluted with $\mathrm{CH}_{2} \mathrm{Cl}_{2}$. The solution washed with $\mathrm{H}_{2} \mathrm{O}(2 \times 10 \mathrm{~mL})$, extracted with $\mathrm{CH}_{2} \mathrm{Cl}_{2}$, and the organic extracts were dried over $\mathrm{Na}_{2} \mathrm{SO}_{4}$ and filtered. The solvent was removed under reduced pressure, and the residue was purified using silica gel column chromatography $\mathrm{CH}_{2} \mathrm{Cl}_{2} /$ EtOAc $(10: 1, v / v)$ but could not be isolated in pure enough form for characterization. HRMS (MALDI): $m / z=789.1948$ (calcd. 789.1956 for $\left.\left[\mathrm{C}_{48} \mathrm{H}_{33} \mathrm{~N}_{6} \mathrm{O}_{2} \mathrm{Zn}\right]\right)$. 
Porphyrin 3e (52 mg, $0.06 \mathrm{mmol})$ and hydrazine hydrate $(24 \%, 0.12 \mathrm{~mL}, 0.60$ mmol) were refluxed in acetic acid $(7 \mathrm{~mL})$ and toluene $(7 \mathrm{~mL})$ for $24 \mathrm{~h}$. The mixture was cooled before being washed using $\mathrm{CH}_{2} \mathrm{Cl}_{2}$ and water. The organic layer was dried over $\mathrm{Na}_{2} \mathrm{SO}_{4}$, and after filtration the solvent was removed in vacuo. The product was purified using silica column chromatography $\mathrm{CH}_{2} \mathrm{Cl}_{2} /$ EtOAc $(10: 1, v / v)$. The targeted compound 4d was isolated as the third fraction. Yield: $6 \mathrm{mg}(0.01 \mathrm{mmol}, 12 \%)$. M. p. $>300{ }^{\circ} \mathrm{C} .-{ }^{1} \mathrm{H}$ NMR (400 MHz, $\left.\mathrm{CDCl}_{3}\right): \delta=3.96\left(\mathrm{~s}, 3 \mathrm{H}, \mathrm{OCH}_{3}\right), 4.00\left(\mathrm{~s}, 3 \mathrm{H}, \mathrm{OCH}_{3}\right), 4.03(\mathrm{~s}, 3 \mathrm{H}$, $\mathrm{OCH}_{3}$ ), 7.19-7.21 (m, 3H, $\left.\mathrm{C}_{6} \mathrm{H}_{4}-H\right)$, 7.33-7.38 (m, 3H, $\mathrm{C}_{6} \mathrm{H}_{4} / \mathrm{Ph}-H$ ), 7.49 (app br.s, 3H, $\left.\mathrm{C}_{6} \mathrm{H}_{4}-H\right), 7.56-7.67\left(\mathrm{~m}, 6 \mathrm{H}, \mathrm{C}_{6} \mathrm{H}_{4} / \mathrm{Ph}-H\right), 7.73-7.80\left(\mathrm{~m}, 8 \mathrm{H}, \mathrm{C}_{6} \mathrm{H}_{4} / \mathrm{Ph}-H\right), 8.78\left(\mathrm{~s}, 1 \mathrm{H}, H_{\beta}\right)$, 8.86-8.92 (m, 3H, $\left.H_{\beta}\right), 8.94\left(\mathrm{~s}, 1 \mathrm{H}, H_{\beta}\right), 9.00-9.02 \mathrm{ppm}\left(\mathrm{m}, 2 \mathrm{H}, H_{\beta}\right) .-{ }^{13} \mathrm{C} \mathrm{NMR}(100$ $\left.\mathrm{MHz}, \mathrm{CDCl}_{3}\right): \delta=55.3,55.4,55.4,105.7,113.0,113.2,113.3,113.6,113.9,120.3$, $120.4,120.7,121.1,121.2,121.5,121.6,122.7,126.6,127.0,127.1,127.2,127.4,127.6$, $127.7,128.1,128.7,128.9,130.7,131.5,132.4,132.4,132.5,132.6,134.0,135.3,140.9$, $143.5,143.7,143.9,147.2$, 147.7, 149.8, 150.4, 150.8, 151.0, 151.5, 157.5, 157.6, 157.7, 167.6, 171.9 ppm. - UV/Vis $\left(\mathrm{CH}_{2} \mathrm{Cl}_{2}\right): \lambda_{\max }=429,494,555,597,705$ nm. - HRMS (MALDI): $m / z=894.2290$ (calcd. 894.2297 for $\left[\mathrm{C}_{55} \mathrm{H}_{48} \mathrm{~N}_{6} \mathrm{O}_{3} \mathrm{Zn}\right]$ ).

\section{Synthesis of dimer 6}

Bromoporphyrin dimer 5 (30 mg, $0.02 \mathrm{mmol})$, diphenylacetylene (12 mg, 0.07 $\mathrm{mmol})$ and $(o-\mathrm{Tol})_{3} \mathrm{P}(3 \mathrm{mg}, 0.01 \mathrm{mmol})$ were added to a $25 \mathrm{~mL}$ Schlenk tube and dried under high vacuum for $0.25 \mathrm{~h}$. Toluene ( $3 \mathrm{~mL}$ ) was added and the solution was degassed via three freeze-pump-thaw cycles. $\mathrm{Pd}_{2}(\mathrm{dba})_{3}(2 \mathrm{mg}, 0.002 \mathrm{mmol})$ and $N, N$ dicyclohexylmethylamine $(45 \mathrm{mg}, 0.23 \mathrm{mmol}$ ) were added, and the reaction was heated to $110{ }^{\circ} \mathrm{C}$ and stirred at this temperature for $24 \mathrm{~h}$, shielded from ambient light. The reaction mixture was filtered through a short plug of silica using $\mathrm{CH}_{2} \mathrm{Cl}_{2}$ as eluent. The solvents were removed in vacuo, and the residue was subjected to column chromatography (silica, $\mathrm{CH}_{2} \mathrm{Cl}_{2} /$ hexane, $2: 1,4: 1, v / v$ ) to yield one main fraction, orange in color. Solvents were removed to give a dark solid 6 (28 mg, $0.02 \mathrm{mmol}, 78 \%$ ). M. p. $>300{ }^{\circ} \mathrm{C} .-R_{\mathrm{f}}=0.21\left(\mathrm{CH}_{2} \mathrm{Cl}_{2} / n\right.$-hexane $\left.=3: 1, v / v\right) .-{ }^{1} \mathrm{H}$ NMR $\left(600 \mathrm{MHz}, \mathrm{CDCl}_{3}\right): \delta=$ $3.81\left(\mathrm{~s}, 6 \mathrm{H}, \mathrm{OCH}_{3}\right), 3.85\left(\mathrm{~s}, 6 \mathrm{H}, \mathrm{OCH}_{3}\right), 6.93\left(\mathrm{~s}, 1 \mathrm{H}, H_{\beta}\right), 6.97\left(\mathrm{~s}, 1 \mathrm{H}, H_{\beta}\right), 7.07-7.08(\mathrm{~d}, J$ $\left.=8.2 \mathrm{~Hz}, 2 \mathrm{H}, \mathrm{C}_{6} \mathrm{H}_{4}-H\right), 7.12-7.13\left(\mathrm{~d}, J=8.2 \mathrm{~Hz}, 2 \mathrm{H}, \mathrm{C}_{6} \mathrm{H}_{4}-H\right), 7.23-7.27$ (m, 4H, aryl- 
$H), 7.38-7.41\left(\mathrm{~m}, 24 \mathrm{H}\right.$, aryl- $\left.H / H_{\beta}\right), 7.59-7.60(\mathrm{~d}, J=7.2 \mathrm{~Hz}, 6 \mathrm{H}$, aryl- $H), 7.69-7.71(\mathrm{~m}$, $\left.2 \mathrm{H}, H_{\beta}\right), 7.79-7.81(\mathrm{~d}, J=6.8 \mathrm{~Hz}, 4 \mathrm{H}$,aryl- $H), 7.86-7.88(\mathrm{~m}, 2 \mathrm{H}$, aryl- $H), 8.06-8.07 \mathrm{ppm}$ $\left(\mathrm{d}, J=4.8 \mathrm{~Hz}, 2 \mathrm{H}, H_{\beta}\right) .-{ }^{13} \mathrm{C}$ NMR $\left(150 \mathrm{MHz}, \mathrm{CDCl}_{3}\right): \delta=55.2,55.3,113.1,113.3$, $119.1,119.2,119.5,120.0,123.9,124.9,125.5,126.4,126.6,126.9,127.3,127.4,127.5$, $127.6,127.9,128.1,128.3,128.5,128.7,128.8,130.1,130.4,134.2,134.3,134.5,135.7$, 137.1, 141.2, 142.7, 143.4, 149.7, 150.3, 150.7, 151.5, 152.7, 153.1, 153.8, 154.4, 157.7, 157.9, 163.9 ppm. - UV/Vis $\left(\mathrm{CH}_{2} \mathrm{Cl}_{2}\right): \lambda_{\max }(\log \varepsilon)=410$ (5.46), $513 \mathrm{~nm}$ (5.54). - HRMS (MALDI): $m / z=1518.3477$ (calcd. 1518.3505 for $\left[\mathrm{C}_{96} \mathrm{H}_{62} \mathrm{~N}_{8} \mathrm{O}_{4} \mathrm{Zn}_{2}\right]$ ).

\section{Trimer 11}

Bromoporphyrin 10 (48 mg, $0.07 \mathrm{mmol})$ and dimer 9 (129 mg, $0.07 \mathrm{mmol})$ were added to a $25 \mathrm{~mL}$ Schlenk flask and dried under high vacuum. Anhydrous toluene $(7 \mathrm{~mL})$ and $(o-\mathrm{Tol})_{3} \mathrm{P}(4.5 \mathrm{mg}, 0.01 \mathrm{mmol})$ were added, and the solution was degassed by three freeze-pump-thaw cycles. $\quad \mathrm{Pd}_{2}(\mathrm{dba})_{3} \quad(4.3 \mathrm{mg}, \quad 0.005 \mathrm{mmol}$, $)$ and $N, N$ dicyclohexylmethylamine $(0.08 \mathrm{~mL}, 0.35 \mathrm{mmol})$ were added to the flask and the mixture stirred at $120^{\circ} \mathrm{C}$ for $24 \mathrm{~h}$ in the dark. The solvent was evaporated, and the residue was dissolved in $\mathrm{CH}_{2} \mathrm{Cl}_{2}$. This solution was passed through silica gel using $n$-hexane/ $\mathrm{CH}_{2} \mathrm{Cl}_{2}$ $=10: 1(\mathrm{v} / \mathrm{v})$ in order to separate a first orange fraction, the green fraction (dimers in excess) and the brown fraction (trimer). Then, the organic solvents were evaporated. To isolate 11, preparative TLC (silica) was used ( $n$-hexane $\left./ \mathrm{CH}_{2} \mathrm{Cl}_{2}=5: 1, \mathrm{v} / \mathrm{v}\right)$. Yield $(2 \mathrm{mg}$, $<2 \%) . R_{\mathrm{f}}=0.31\left(n\right.$-hexane/ $\left.\mathrm{CH}_{2} \mathrm{Cl}_{2}=3: 1, v / v\right)$. - HRMS (MALDI): $m / z=1802.3781$ (calcd. 1802.3750 for $\left[\mathrm{C}_{116} \mathrm{H}_{68} \mathrm{~N}_{12} \mathrm{Ni}_{3}\right]$ ).

\section{Acknowledgement}

This work was supported by grants from Science Foundation Ireland (SFI P.I. 09/IN.1/B2650 and 12/TIDA/B2381).

[1] T. D. Lash, J. Porphyrins Phthalocyanines 2001, 5, 267.

[2] M. O. Senge, Chem. Commun. 2011, 47, 1943.

[3] V. V. Roznvatovskiy, C. H. Lee, J. L. Sessler, Chem Soc. Rev. 2013, 42, 1921.

[4] A. Nakano, N. Aratani, H. Furuta, A. Osuka, Chem. Commun. 2001, 1920. 
[5] T. S. Balaban, Acc. Chem. Res. 2005, 38, 612 .

[6] H. Shinokubo, A. Osuka, Chem. Commun. 2009, 1011.

[7] M. Mizumura, H. Shinokubo, A. Osuka, Angew. Chem. Int. Ed. 2008, 47, 5378.

[8] D.-M. Shen, C. Liu, Q.-Y. Chen, Chem. Commun. 2005, 4982.

[9] A. K. Sahoo, S. Mori, H. Shinokubo, A. Osuka, Angew. Chem. Int. Ed. 2006, 45, 7972.

[10] R. C. Larock, M. J. Doty, Q. Tian, J. M. Zenner, J. Org. Chem. 1997, 62, 7536.

[11] G. Wu, A. L. Rheingold, S. J. Geib, R. F. Heck, Organometallics 1987, 6, 1941.

[12] S. Tokuji, Y. Takahashi, H. Shinmori, H. Shinokubo, A. Osuka, Chem. Commun. 2009, 1028.

[13] A. A. Ryan, M. O. Senge, Eur. J. Org. Chem. 2013, 3700.

[14] N. Hoffmann, Chem. Rev. 2008, 108, 1052.

[15] V. G. Kharchenko, L. I. Markova, O. V. Fedotova, N. V. Pchelintseva, Khim. Geterot. Soed. 2003, 1283; Chem. Heterocycl. Comp. 2003, 39, 1121.

[16] C. G. Overberger, J. J. Monagle, J. Am. Chem. Soc. 1956, 78, 4470.

[17] X. Huang, J. Doi, D. Li, D. Wang, J. Chil. Chem. Soc. 2009, 54, 20.

[18] J. A. VanAllan, G. A. Reynolds, J. Org. Chem. 1968, 33, 1102.

[19] T. S. Balaban, A. T. Balaban, in Science of Synthesis; Houben-Weyl Methods of Molecular Transformations, Vol. 14, Georg Thieme Verlag: Stuttgart, 2003, Chapter 14.1, pp. 11-200.

[20] A. T. Balaban, T. S. Balaban. in Science of Synthesis Knowledge Updates, E. J. Thomas, A. P. Dobbs, Eds., Thieme: Stuttgart, Vol. 2013/3, Section 14.1.5, pp. 145-216.

[21] A. A. Ryan, S. Plunkett, A. Casey, T. McCabe, M. O. Senge, Chem. Commun. 2014, 50, 353.

[22] M. O. Senge, Y. M. Shaker, M. Pintea, C. Ryppa, S. S. Hatscher, A. Ryan, Y. Sergeeva, Eur. J. Org. Chem. 2010, 237. 
Figure for Content Section:

Bromoporphyrin or 1,5-diketone porphyrinoid

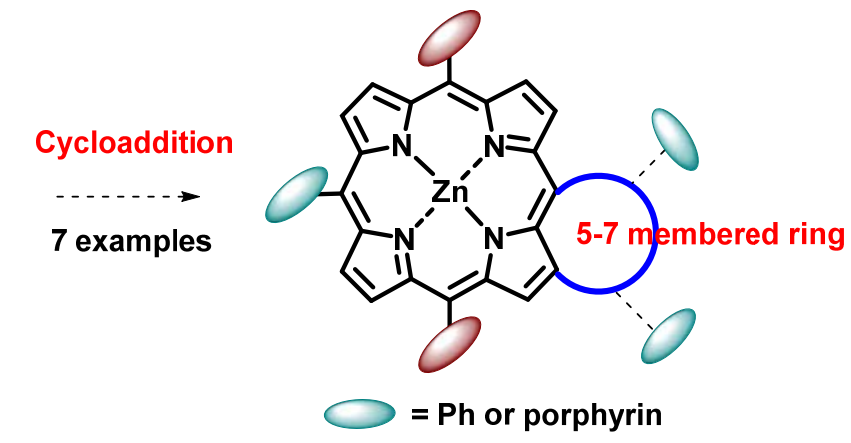

